\title{
PENERAPAN MODEL PEMBELAJARAN DISCOVERY LEARNING UNTUK MENINGKATKAN KEMAMPUAN BERPIKIR KRITIS DAN HASIL BELAJAR KIMIA
}

\author{
Amallia Nugrahaeni. ${ }^{1}$, , I Wayan Redhana, ${ }^{2}$, I Made Arya Kartawan, ${ }^{3}$ \\ 1 Universitas Pendidikan Ganesha \\ 2Universitas Pendidikan Ganesha \\ ${ }^{3}$ SMA Negeri 2 Singaraja
}

\begin{abstract}
Abstrak
Penelitian ini bertujuan untuk meningkatkan kemampuan berpikir kritis dan hasil belajar kimia melalui model pembelajaran Discovery Learning pada materi laju reaksi. Penelitian ini dilakukan di SMA Negeri 2 Singaraja di kelas XI MIA 2 semester gasal tahun ajaran 2016/2017 subjek berjumlah 29 siswa. Jenis penelitian ini adalah penelitian tindakan kelas yang terdiri dari perencanaan, pelaksanaan tindakan, observasi dan refleksi dengan menggunakan model pembelajaran Discovery Learning. Tes digunakan untuk mengukur hasil belajar kemampuan awal siswa dan hasil belajar, dan lembar observasi digunakan untuk mengukur keterampilan berpikir kritis siswa.

Pembelajaran dengan menggunakan model Discovery Learning terbukti efektif dalam meningkatkan hasil belajar siswa dan keterampilan berpikir kritis siswa. Keberhasilan penerapan dalam meningkatkan hasil belajar siswa ditunjukan dengan adanya perubahan dalam proses siklus I kenaikan nilai ratarata kelas setelah adanya tindakan dari semula pretest sebesar 85,70 \% naik menjadi $89,70 \%$ pada saat postest. Peningkatan jumlah peserta didik yang mencapai nilai KKM sebesar 17,24\%. Pada siklus II keberhasilan ditunjukan dengan kenaikan nilai rata-rata kelas setelah adanya tindakan dari semula pretest sebesar $62,1 \%$ naik menjadi $79,3 \%$ pada saat postest. Peningkatan jumlah peserta didik yang mencapai nilai KKM sebesar 6,8\%. Nilai yang dicapai masih dikategorikan dalam kriteria Sangat Baik.

Berdasarkan analisis keterampilan berpikir kritis siswa, keberhasilan penerapan dalam meningkatkan keterampilan berpikir kritis siswa ditunjukan oleh persentase berpikir kritis siswa yang berada pada kriteria kritis dari 80,57\% pada pertemuan kedua siklus I meningkat pada kriteria sangat kritis menjadi pada kriteria $88,5 \%$ pada pertemuan kedua siklus II. Kesimpulan penelitian ini adalah penerapan pembelajaran dengan menggunakan model Discovery Learning terbukti efektif dalam meningkatkan hasil belajar siswa dan keterampilan berpikir kritis siswa SMA Negeri 2 Singaraja di kelas XI MIA 2 semester gasal tahun ajaran $2016 / 2017$
\end{abstract}

\author{
Kata-kata kunci: \\ Penelitian tindakan kelas, \\ Discovery learning, hasil \\ belajar, keterampilan \\ berpikir kritis, laju reaksi
}

\section{Pendahuluan}

Kurikulum 2013 yang berlaku saat ini menuntut siswa untuk berperan aktif dalam proses belajar mengajar sehingga diperlukan strategi pembelajaran yang mendukung tercapai tujuan tersebut. Siswa sebagai subjek belajar harus berperan aktif dalam pembelajaran. keaktifan siswa dinilai dari peranannya dalam pembelajaran, seperti bertanya, menjawab pertanyaan, dan memberi tanggapan. Di samping itu, keaktifan siswa merupakan bentuk pembelajaran mandiri, yaitu siswa berusaha mempelajari segala sesuatu atas kehendak dan kemampuannya atau usahanya sendiri, sehingga dalam hal ini guru hanya berperan sebagai pembimbing, motivator, dan fasilitator. Dalam proses pembelajaran guru mempunyai peranan penting dalam menciptakan kondisi pembelajaran yang mendorong peran aktif dan pemahaman siswa. Usaha untuk menciptakan kondisi pembelajaran yang dapat melibatkan 
peran aktif siswa membutuhkan kemampuan guru dalam menerapkan model pembelajaran yang sesuai dan bervariasi sehingga siswa akan berperan aktif dan tercapai hasil yang diharapkan.

Dalam pembelajaran kimia diharapkan tidak hanya memberikan pengetahuan sebanyak-banyaknya kepada siswa, tetapi mampu merangsang berpikir, bersikap ilmiah dan kreatif serta tanggung jawab siswa terhadap peristiwa sehari-hari yang relevan dengan pelajaran kimia. Selain memahami konsep kimia, siswa diharapkan dapat mengaplikasikannya dalam kehidupan sehari-hari serta menyadari dampaknya terhadap lingkungan dan berusaha mencari solusinya sehingga dapat melestarikan lingkungan sekitarnya. melihat kenyataan ini diperlukan suatu solusi pembelajaran, dengan model pembelajaran yang sesuai diharapkan siswa akan lebih aktif dan dapat mengumpulkan informasi dengan stimulus pertanyaan efektif sehingga mewujudkan kompetensi siswa, sehingga pembelajaran dapat diterima siswa dan guru. Hakikat pembelajaran kimia sebagai bagian dari sains tidak lepas dari kegiatan minds on, hands on, dan hearts on, yaitu siswa mampu mengasah keterampilan berpikir, praktek, dan berbudi pekerti luhur. Ketiga keterampilan tersebut, siswa diharapkan dapat aktif dalam kegiatan berpikir dan berproses untuk mengasah keterampilan sains sehingga siswa dapat menemukan konsep-konsep baru dari kegiatan belajar mereka serta berkarakter kuat dalam kehidupan sosialnya.

Pendidikan pada dasarnya merupakan interaksi antara pendidik dengan siswa, untuk mencapai tujuan pendidikan yang berlangsung dalam lingkungan tertentu. Interaksi ini disebut interaksi pendidikan, yaitu saling pengaruh antara pendidik dengan siswa (Sukmadinata, 2011: 3). Fungsi pendidikan adalah menyiapkan siswa. Menyiapkan diartikan bahwa siswa pada hakikatnya belum siap, tetapi perlu disiapkan dan sedang menyiapkan dirinya sendiri (Hamalik, 2013: 2).

Pada proses pembelajaran, pengembangan potensi\&potensi siswa harus dilakukan secara menyeluruh dan terpadu. Pengembangan potensi siswa secara tidak seimbang menjadikan pendidikan cenderung lebih peduli pada pengembangan satu aspek kepribadian tertentu saja. Padahal sesungguhnya pertumbuhan dan perkembangan siswa merupakan tujuan yang ingin dicapai oleh semua sekolah dan guru.

Model pembelajaran Discovery Learning merupakan suatu rangkaian kegiatan belajar yang melibatkan secara maksimal seluruh kemampuan siswa untuk mencari dan menyelidiki secara sistematis, kritis, logis, analitis sehingga mereka dapat merumuskan sendiri penemuannya. Pengetahuan yang diperoleh dengan belajar penemuan menunjukkan beberapa kebaikan yaitu, pengetahuan itu bertahan lama atau lebih mudah diingat bila dibandingkan dengan pengetahuan yang dipelajari dengan cara-cara lain, hasil belajar penemuan mempunyai efek transfer yang lebih baik dan secara menyeluruh belajar penemuan dapat meningkatkan penalaran siswa dan keterampilan untuk berpikir secara kritis. Dipilihnya model pembelajaran Discovery Learning dengan pendekatan saintifik karena model ini memberikan kesempatan bagi siswa untuk berpikir, menemukan, berpendapat, dan saling bekerja sama melalui aktivitas belajar secara ilmiah, sehingga dapat melatih dan meningkatkan keterampilan berfikir kritis dan pemecahan masalah serta mendapatkan pengetahuan konsep-konsep penting yang nantinya akan berdampak pada peningkatan hasil belajar.

Sistem pembelajaran Discovery Learning, guru tidak langsung menyajikan bahan pelajaran, akan tetapi siswa diberi kesempatan untuk menemukan suatu persoalan dengan menggunakan pendekatan problem solving. Menurut Anitah (2009) Pembelajaran Discovery Learning mempunyai langkah-langkah sebagai berikut : (1) Identifikasi masalah, (2) Mengembangkan kemungkinan solusi (hipotesis), (3) Pengumpulan data, (4) Analisis dan interpretasi data (5)Uji kesimpulan (hlm. 57).

Kelima langkah-langkah model pembelajaran Discovery Learning menurut Sri Anitah tersebut, dapat dijelaskan sebagai berikut: 1). Identifikasi masalah, pada tahap ini guru memberikan kesempatan kepada siswa untuk mencari dan mengumpulkan sebanyak mungkin masalah yang berhubungan dengan tema yang akan dipelajari. 2). Mengembangkan solusi, pada tahap ini siswa diajak untuk membuat suatu hipotesis atas masalah yang telah ditentukan sebelumnya. 3). Pengumpulan data, pada tahap ini guru memberikan waktu kepada siswa untuk mengumpulkan data yang terkait dengan masalah. Data tersebut bisa dari observasi langsung, internet, buku, eksperimen, ataupun sumber-sumber yang lain. 4). Analisis dan intepretasi data, pada tahap ini siswa menganalisis data hasil temuannya, lalu mengembangkan pernyataan pendukung data. Setelah itu data diuji hipotesis dan disimpulkan. 5). Uji kesimpulan, setelah ada kesimpulan dari siswa, muncullah data baru dan ditahap ini dilakukan pengujian terhadap hasil kesimpulan. 
Jika terjadi kekurangan dapat dilakukan revisi kesimpulan tersebut.

Menurut Kemendikbud (2013) Model pembelajaran Discovery Learning memiliki dua langkah operasional yang harus dilaksanakan yaitu langkah persiapan dan pelaksanaan. 1) Langkah Persiapan a). Menentukan tujuan pembelajaran b). Melakukan identifikasi karakteristik siswa c). Memilih materi pelajaran d). Menentukan topik yang harus dipelajari siswa secara induktif. e). Mengembangkan Metode

Tempat penelitian ini dilaksanakan di kelas XI MIA 2 SMA Negeri 2 Singaraja terletak di Jalan Srikandi Baktiseraga Singaraja. Kegiatan penelitian ini dilaksanakan pada semester gasal tahun pelajaran 2016/2017 selama 2 bulan mulai dari minggu pertama bulan oktober sampai dengan minggu kedua bulan November yang meliputi penyusunan proposal sampai dengan penyusunan laporan Penelitian Tindakan Kelas. Penelitian tindakan kelas ini dilaksanakan secara kolaboratif partisipatif antara peneliti dengan guru kimia kelas XI MIA 2 SMA Negeri 2 Singaraja. Subjek Penelitian tindakan kelas adalah peserta didik kelas XI MIA 2 SMA Negeri 2 Singaraja tahun pelajaran 2016/2017 dengan jumlah peserta didik sebanyak 29 orang terdiri dari 14 peserta didik putra dan 15 peserta didik putri. Sedangkan objek penelitian ini adalah peningkatan hasil belajar kimia dan keterampilan berpikir kritis peserta didik pada materi laju reaksi.

Metode penelitian yang digunakan pada penelitian ini adalah metode Penelitian Tindakan Kelas (PTK) dengan dua siklus. Masing-masing siklus terdiri atas tahap-tahap perencanaan, tindakan, observasi dan refleksi. Penelitian ini dilakukan dengan tujuan untuk memperbaiki kualitas pembelajaran serta mengatasi berbagai permasalahan yang terdapat di dalam kelas seperti keterampilan berpikir kritis dan hasil belajar kimia peserta didik. Siklus PTK yang dilaksanakan dengan mengacu kepada teori Arikunto (2006 : 16)

Penelitian ini terdiri dari 2 siklus. Setiap siklus dilakukan dalam 2 kali pertemuan. Hal ini dimaksudkan agar peserta didik dan guru dapat beradaptasi dengan model pembelajaran yang diterapkan. Sehingga hasil penelitian tindakan kelas dapat dimanfaatkan dalam proses belajar mengajar selanjutnya. Agar penelitian tindakan kelas ini berhasil dengan baik tanpa hambatan yang menganggu kelancaran peneleitian, peneliti menyusun tahapan-tahapan yang dilalui dalam penelitian tindakan kelas, yaitu : (1) perencanaan, (2) Pelaksanaan, (3) Observasi dan (4) refleksi.

Pada tahap perencanaan tindakan yang bahan-bahan ajar. f). Mengatur topik-topik pelajaran dari yang sederhana ke kompleks, dari yang konkret ke abstrak, atau dari tahap enaktif, ikonik sampai ke simbolik. g). Melakukan penilaian proses dan hasil belajar siswa. 2) Pelaksanaan Tahap pelaksanaan model Discovery Learning menurut Kementerian Pendidikan dan Kebudayaan (2013) terdiri dari beberapa langkah yaitu Stimulation; Problem statement; Data collection; Verification; Generalization.

akan dilakukan berdasarkan masalah yang ada yaitu penerapan model pembelajaran Discovery Learning pada kegiatan belajar mengajar kimia di SMAN 2 Singaraja. Pada tahap ini peneliti merancang perangkat pembelajaran yang terdiri dari silabus, rencana pelaksanaan pembelajaran, lembar kerja peserta didik, dan lembar pengamatan aktivitas guru dan peserta didik.

Dalam pelaksanaan penelitian juga melibatkan pengamat dan supervisor, tugas dari pengamat tersebut adalah untuk melihat aktivitas guru dan peserta didik selama pembelajaran berlangsung, hal ini dilakukan untuk memberi masukan dan pendapat terhadap pelaksanaan pembelajaran yang dilakukan, shingga masukan-masukan dari pengamat dapat dipakai untuk memperbaiki pembelajaran pada siklus berikutnya. Pengamatan ditujukan untuk melihat aktivitas guru dan peserta didik selama proses berlangsungnya pembelajaran.

Hasil yang didapat dalam tahap observasi dikumpulkan serta dianalisis. Dari hasil observasi guru dapat merefleksikan diri dengan melihat data observasi guru dan peserta didik selama pembelajaran berlangsung. Hasil yang diperoleh dari tahap observasi kemudian dikumpulkan dan dianalisa, dari hasil observasi apakah kegiatan yang dilakukan telah didapat meningkatkan hasil belajar kimia dan keterampilan berpikir kritis pada mata pelajaran kimia peserta didik di kelas XI MIA 2 SMAN 2 Singaraja.

\section{Hasil}

Data yang diperoleh dari hasil penelitian berupa angka-angka dianalisis untuk membuktikan hipotesis yang telah diajukan. Adapun analisis data hasil penelitian tersebut meliputi perolehan masing-masing peserta didik, rata-rata nilai kelas dan ketuntasan klasikal, disamping itu juga akan dibahas. Tes hasil belajar dilakukan pada awal dan akhir siklus 1 dan siklus 2. Hasil tes ini digunakan untuk mengetahu tingkat pemahaman peserta didik terhadap materi laju reaksi yang telah disampaikan oleh guru. Perolehan tes peserta didik pada masing-masing siklus dapat memperlihatkan peningkatan atau penurunan hasil belajar masing-masing peserta didik. 
Apabila digambarkan dalam tabel maka perolehan hasil belajar peserta didik mulai dari sebelum siklus sampai siklus 2 akan tampak sebagai berikut.

Tabel 1. Perolehan nilai tes hasil belajar peserta didik kelas XI MIA 2 Sebelum dan sesudah tindakan

\begin{tabular}{cccccc}
\hline & \multirow{2}{*}{ Nilai awal } & \multicolumn{2}{c}{ Nilai Siklus 1 } & \multicolumn{2}{c}{ Nilai siklus 2 } \\
& & Pretest & Postest & Pretest & Postest \\
\hline Nilai Tertinggi & 89 & 95 & 100 & 96 & 100 \\
Nilai Terendah & 15 & 49 & 44 & 62 & 65 \\
Rata-Rata & 57,03 & 70,45 & 78,28 & 81,64 & 88,45 \\
& 34,50 & 62,1 & 79,3 & 85,7 & 89,7 \\
Ketuntasan (\%) & 10 Peserta & 18 Peserta & 23 Peserta & 24 Peserta & 26 Peserta \\
& didik & didik & didik & didik & didik \\
\hline
\end{tabular}

Dari tabel diatas dapat disimpulkan bahwa terjadi peningkatan nilai rata-rata setiap siklus. Jadi model yang diterapkan ini memberikan dampak positif terhadap proses pembelajaran yang ditinjau dari peningkatan nilai rata-rata kelas yang meningkat setiap siklusnya. Data peningkatan persentase hasil belajar sebelum dan sesudah model Discovery Learning dapat dilihat pada grafik berikut:

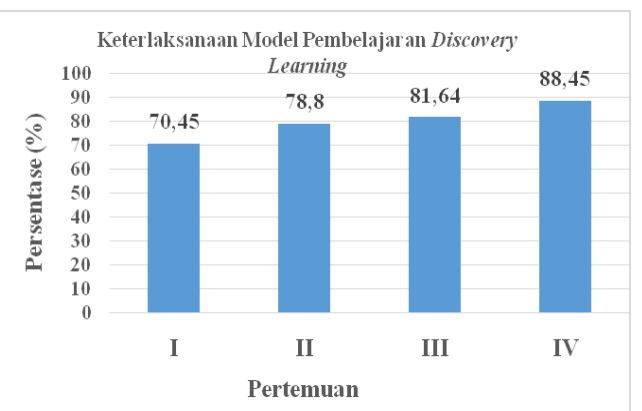

Berdasarkan hasil observasi diperoleh data bahwa keterampilan berpikir kritis dengan menggunakan model Discovery Learning mengalami peningkatan di setiap pertemuan dengan memperbaiki kekurangan yang terjadi di pertemuan sebelumnya. Adapun rincian mengenai peningkatan keterampilan berpikir kritis siswa denggan mengunakan model Discovery Learning dapat dilihat pada tabel dibawah ini:

Tabel 2. Hasil Lembar Observasi Keterampilan Berpikir Kritis

\begin{tabular}{llcccc}
\hline No & Indikator & $\begin{array}{c}\text { Persentase } \\
\text { Pertemuan } 1 \\
(\%)\end{array}$ & $\begin{array}{c}\text { Persentase } \\
\text { Pertemuan } \\
2(\%)\end{array}$ & $\begin{array}{c}\text { Persentase } \\
\text { Pertemuan } \\
3(\%)\end{array}$ & $\begin{array}{c}\text { Persentase } \\
\text { Pertemuan } \\
4(\%)\end{array}$ \\
\hline 1 & Melakukan Pengamatan & 72 & 84 & 84 & 88 \\
2 & Merumuskan hipotesis & 72 & 88 & 88 & 88 \\
3 & Melakukan diskusi & 72 & 72 & 84 & 84 \\
4 & Keterampilan peserta & 76 & 80 & 88 & 88 \\
& didik bertanya & & & & \\
5 & Keterampilan peserta & 68 & 80 & 88 & \\
& didik menjawab & & & & \\
& pertanyaan & & 76 & 84 & 84 \\
6 & Membuat Kesimpulan & 68 & 84 & 84 & \\
7 & Menerapkan konsep & 80 & & & \\
\hline
\end{tabular}

Dari tabel diatas dapat disimpulkan bahwa terjadi peningkatan nilai rata-rata setiap siklus. Jadi model yang diterapkan ini memberikan dampak positif terhadap proses pembelajaran yang ditinjau dari peningkatan nilai rata-rata kelas yang meningkat setiap siklusnya. Sedangkan hubungan peningkatan hasil belajar dan keterampilan berpikir kritis siswa dapat dilihat pada grafik berikut:

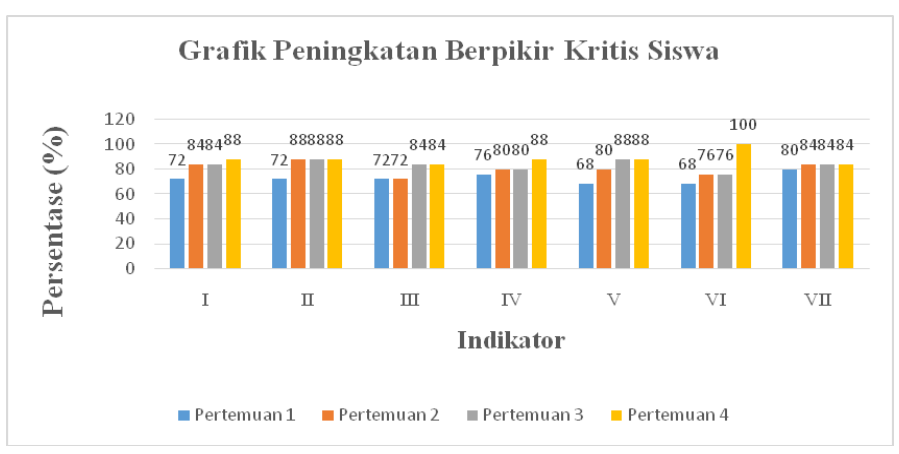




\section{Pembahasan}

Pembelajaran dengan menggunakan model Discovery Learning terbukti efektif dalam meningkatkan keterampilan berpikir luwes peserta didik. Dalam pembelajaran, aktivitas peserta didik selama mengikuti proses pembelajaran diperhatikan. Semakin peserta didik aktif, pembelajaran akan semakin efektif. Hal ini sesuai dengan pernyataan Bell (1978), dalam penemuan peserta didik memiliki kesempatan untuk terlibat secara aktif dalam pembelajaran. Kenyataan menunjukan bahwa partisipasi peserta didik dalam pembelajaran meningkat ketika tahapan penemuan konsep digunakan.

Berdasarkan data hasil belajar siklus I diperoleh nilai rata-rata pretest I sebesar 70,45 nilai tertinggi yang diperoleh peserta didik sebesar 95, dan untuk nilai terendah sebesar 49 sedangkan hasil belajar postest I diperoleh nilai rata-rata postest I sebesar 78,28 nilai tertinggi yang diperoleh peserta didik sebesar 100 dan untuk nilai terendah sebesar 44, sedangkan siklus II diperoleh nilai rata-rata pretest II sebesar 81,64 nilai tertinggi yang diperoleh peserta didik sebesar 96, dan untuk nilai terendah sebesar 62 sedangkan hasil belajar postest II diperoleh nilai rata-rata postest II sebesar 88,45 nilai tertinggi yang diperoleh peserta didik sebesar 100 dan untuk nilai terendah sebesar 65 .

Penerapan model pembelajaran Discovery Learning dapat meningkatkan keterampilan berpikir kritis siswa kelas XI MIA 2 SMA Negeri 2 Singaraja Tahun Ajaran 2016 / 2017. Keberhasilan penerapan ditunjukan dengan adanya perubahan dalam proses siklus I persentase berpikir kritis siswa yang berada pada kriteria kritis dari 72,25\% naik menjadi $80,57 \%$ sedangkan pada siklus II persentase berpikir kritis siswa yang berada pada kriteria kritis dari 83,42 \% naik menjadi pada kriteria sangat kritis 88,5 \%. Berdasarkan hasil observasi diperoleh data bahwa keterampilan berpikir kritis dengan menggunakan model Discovery Learning mengalami peningkatan di setiap pertemuan dengan memperbaiki kekurangan yang terjadi di pertemuan sebelumnya.

Model Discovery Learning berpengaruh pada psikomotorik atau keterampilan peserta didik, dimana pada saat pembelajaran peserta didik dapat berpikir kritis dengan guru memberikan kesempatan kepada peserta didik untuk belajar secara aktif, guru juga memberikan kesempatan untuk menjawab dengan gagasan peserta didik sendiri dalam memecahkan masalah dengan mengembangkan kemampuan analisis dan mengolah informasi yang didapat, peserta didik menjadi lebih terampil berbicara dalam mengemukakan pendapat. Kemudian peserta didik saling berkelompok untuk mendiskusikan hasil jawabannya bersama-sama sehingga aktivitas belajar peserta didik meningkat. Hal ini sesuai dengan pendapat Istiana, Catur dan Sukardjo (2015: 70), menyatakan bahwa model Discovery Learning dapat meningkatkan aktivitas belajar peserta didik.

Peningkatan aktivitas belajar peserta didik ini disebabkan oleh banyak faktor, antara lain model Discovery Learning yang menuntut peserta didik untuk lebih aktif dalam menemukan konsep \& materi, adanya kegiatan diskusi yang melatih peserta didik untuk aktif dalam proses pembelajaran. Dengan adanya diskusi, peserta didik lebih berani dalam menyatakan pendapat, menanggapi pernyataan baik teman maupun guru, dan bertanya mengenai hal\&hal yang belum dipahami. Model Discovery Learning juga berpengaruh pada ranah afektif atau sikap peserta didik terutama pada tahap data collection. Peserta didik dituntut untuk mencatat semua data atau informasi yang diperoleh dari kegiatan pengamatan terhadap gambar guna menemukan konsep \& materi yang diharapkan, sehingga dari kegiatan ini akan terbentuk sikap jujur dan terbuka. Kemampuan berpikir kritis peserta didik juga telah dikembangkan melalui penerapan model Discovery Learning ini.

Salah satu strategi guru dalam mengembangkan keterampilan berpikir kritis dengan praktikum. Perkembangan ini juga nampak terlihat pada saat merancang percobaan yaitu ketika menentukan variabel percobaan, alat-alat dan bahan-bahan percobaan peserta didik sangat aktif bertanya dan antusias dalam mencari tahu jawabannya. metode praktikum peserta didik diberi kesempatan untuk mengalami sendiri atau melakukan sendiri, mengikuti suatu proses, mengamati suatu objek, menganalisis, membuktikan dan menarik kesimpulan sendiri suatu objek, keadaan atau proses tertentu. Dengan demikian peserta didik dituntut untuk mengalami sendiri, mencari kebenaran, atau mencari suatu hukum dan menarik kesimpulan atau proses yang dialaminya. Dengan pembelajaran praktikum ini keterampilan berpikir kritis peserta didik dapat ikut berkembang. Karena praktikum bukanlah sekedar untuk mempresentasikan apakah reaksinya cocok dengan teori tetapi juga harus mengembangkan proses berpikir dengan timbul pertanyaan mengapa reaksi demikian dan sebagainya.

Dari data diatas dapat disimpulkan bahwa terjadi peningkatan nilai rata-rata setiap 
siklus. Jadi model Discovery Learning yang diterapkan ini memberikan dampak positif terhadap proses pembelajaran yang ditinjau dari peningkatan nilai rata-rata kelas yang meningkat setiap siklusnya.

Penutup

Penerapan model pembelajaran Discovery Learning dapat meningkatkan hasil belajar kimia kelas XI MIA 2 SMA Negeri 2 Singaraja Tahun Ajaran 2016/2017. Keberhasilan penerapan ditunjukan dengan adanya perubahan dalam proses siklus I kenaikan nilai rata-rata kelas setelah adanya tindakan dari semula pretest sebesar 85,70 \% naik menjadi $89,70 \%$ pada saat postest. Peningkatan jumlah peserta didik yang mencapai nilai KKM sebesar $17,24 \%$. Nilai yang dicapai masih dikategorikan dalam kriteria Baik dan sudah mencapai indikator keberhasilan yang peneliti tentukan. Saat pretest jumlah peserta didik yang tuntas sebanyak 18 siswa kemudian saat postest naik menjadi 23 siswa. Pada siklus II keberhasilan ditunjukan dengan kenaikan nilai rata-rata kelas setelah adanya tindakan dari semula pretest sebesar $62,1 \%$ naik menjadi $79,3 \%$ pada saat postest. Peningkatan jumlah peserta didik yang mencapai nilai KKM sebesar 6,8\%. Nilai yang dicapai masih dikategorikan dalam kriteria Sangat Baik dan sudah mencapai indikator keberhasilan yang peneliti tentukan. Saat pretest jumlah peserta didik yang tuntas sebanyak 24 siswa kemudian saat postest naik menjadi 26 siswa.

Penerapan model pembelajaran Discovery Learning dapat meningkatkan keterampilan berpikir kritis siswa kelas XI MIA 2 SMA Negeri 2 Singaraja Tahun Ajaran 2016 / 2017. Keberhasilan penerapan ditunjukan dengan adanya perubahan dalam proses siklus I persentase berpikir kritis siswa yang berada pada kriteria kritis dari 72,25\% naik menjadi $80,57 \%$ sedangkan pada siklus II persentase berpikir kritis siswa yang berada pada kriteria kritis dari $83,42 \%$ naik menjadi pada kriteria sangat kritis 88,5\%.

\section{Daftar Pustaka}

Abidin, Yunus. 2014. Desain Sistem Pembelajaran dalam Konteks Kurikulum 2013. PT Refika Aditama. Bandung.

Ahmad. 2004. Student-Centered Learning Berbasis ICT. Makalah.ppp.ugm.ac.id/wpcontent/uploads/jte_e0ccce.doc. Diakses pada 24 September 2016. 14.06 WIB.

Aisyah, Nyimas,dkk. 2007. Pengembangan Pembelajaran Matematika SD.
Dikjen Dikti Depdiknas. Jakarta.

Aqib, Zainal, dkk. 2009. Penelitian Tindakan Kelas untuk Guru SD, SLB, \& TK. Yrama Widya. Bandung.

Arikunto, Suharsimi. 2006. Penelitian Tindakan Kelas. Bumi Aksara. Jakarta

Badarudin. 2012. Modul Konsep Belajar dan Pembelajaran. UNY. Yogyakarta.

Budiningsih, Asri. 2005. Belajar dan Pembelajaran. Rineka Cipta. Jakarta. DeBono, Edward.1990. Mengajar Berpikir. Erlangga. Jakarta.

Dike, Daniel. 2010. Peningkatan Kemampuan Berpikir Kritis Siswa dengan Model TASC (Thinking Actively in a Social Context) pada Pembelajaran IPS. Jurnal Penelitian.

Eggen, Paul \& DonKauchak. 2012. Strategi dan Model Pembelajaran. PT. Indeks. Jakarta.

Hamalik, Oemar. 2001. Proses Belajar Mengajar. PT. Bumi Aksara. Jakarta.

Hanafiah, Nanang dan Cucu. 2010. Konsep Strategi Pembelajaran. PT Refika Aditama. Bandung.

Herdian.2010. Metode-Pembelajaran-DiscoveryPenemuan. PT Refika Aditama. Bandung.

Hosnan. 2014. Pendekatan Scientific dan Kontekstual dalam Pembelajaran Abad 21. Ghalia Indonesia. Bogor.

Isjoni. 2007. Cooperative Learning. Alfabeta. Bandung.

Jihad, Asep \& Abdul Haris. 2008. Evaluasi pembelajaran. Multi Pressindo. Yogyakarta.

James E. Brady. 1999. Kimia Untuk Universitas Asas \& Struktur Jilid 1. Binarupa Aksara. Jakarta.

Keenan,dkk. 1984. Kimia Untuk Universitas Jilid 1. Erlangga. Jakarta.

Kurniasih, Imas dan Berlin. 2014. Implementasi Kurikulum 2013 Konsep dan Penerapan. Kata Pena. Surabaya.

Kuswana, Wowo Sunaryo. 2011. Taksonomi Berpikir. PT Remaja Rosda karya. Bandung

Lelana, Dwi Putra. 2010. Penerapan Model Pembelajaran Berbasis . Masalah untuk Meningkatkan Kemampuan Berpikir Kritis dan Hasil Belajar Siswa. Skripsi. www.academia.edu/1208233/. Diakses tanggal 27 September pukul 11.07

Muijs, D. \& Reynolds. 2008. Effective Teaching Teori dan Aplikasi. Pustaka Pelajar. Yogyakarta. 
Murti, Bhisma. 2009. Berpikir Kritis (Critical Thinking) Seri Ilmiah.Fakultas Kedokteran Universitas Sebelas Maret. Diakses dari alamat http://researchengenis.com. pada tanggal 3 Oktober 2015.

Nashar. 2004. Peranan Motivasi dan Kemampuan Awal. Delia Press..Jakarta.

Paul, R. \& L. Elder. 2007. The Miniature Guide to Critical Thingking Concepts and Tools. www.criticalthinking.org.

Purwanto, Ngalim. 2008. Prinsip-prinsip dan Teknik Evaluasi Pengajaran. Remaja Rosdakarya. Bandung.

Rosyada,Dede. 2004. Paradigma Pendidikan Demokratis Sebuah Modal

Masyarakat dalam Penyelenggaraan Pendidikan. Prenada Media. Jakarta.

Sani, Ridwan Abdullah. 2014. Pembelajaran Saintifik untuk Implementasi
Kurikulum 2013. Bumi Aksara. Jakarta.

Sudjana, Nana. 2011. Penilaian hasil proses belajar mengajar. Remaja Rosdakarya. Bandung.

Suherman. (2001). Common TexBook Strategi Pembelajaran Matematika

Kontemporer. Bandung: Jurusan Pendidikan Matematika UPI Bandung.

Susanto, Ahmad. 2013. Teori Belajar dan Pembelajaran di SD. Kencana Prenada Media Group. Jakarta.

Suwangsih, Erna \& Tiurlina. 2006. Model Pembelajaran Matematika. UPI PRESS. Bandung.

Tim Penyusun. 2003. Undang-undang Republik Indonesia Nomor 20 Tahun 2003 tentang Sistem Pendidikan Nasional. Depdiknas. Jakarta.

dan Menengah (Peraturan ..........Mendiknas No. 22 dan 23 tahun 2006). Depdiknas. Jakarta. 